\title{
Tattoo toxicology, an upcoming complex scientific issue
}

\author{
Hermann M. Bolt ${ }^{1} \mathbb{D} \cdot$ Jan G. Hengstler ${ }^{1}$ \\ Received: 26 May 2020 / Accepted: 18 June 2020 / Published online: 30 June 2020 \\ (c) The Author(s) 2020
}

\begin{abstract}
A Guest Editorial in Archives of Toxicology by Schreiver and Luch (2016) has pointed to the new field of tattoo toxicology and to existing data gaps. A global trend is now noted towards larger and more colourful tattoos (Bagot 2020). Yet, tattoo legislation in Europe is still based on an exposure scenario of placing the product on top of the skin, rather than right into the middle of living tissue beneath the epidermal skin barrier (Schreiver and Luch 2016).
\end{abstract}

\section{Toxic effects of tattooing}

From a consumer's aspect, there is a notable increase in the incidence of "itchy tattoos" (Kluger 2019a). From a clinical point of view, hypersensitivity reactions to tattoo inks, mostly elicited by specific colorants, are the most common tattoo complications, and these are unpredictable (Kluger 2019b). Hypersensitivity may appear after a latency of several months or even years; the state is mostly chronic, and it is resistant against treatment with corticoids. Moreover, epicutaneous patch testing with specific tattoo inks is usually negative, because the reaction is due to hapten formation within the inner skin, by combination with a protein and/or by the involvement of degradation products (Kluger 2019b; Bagot 2020).

Considerable progress has been made in tattoo pigment analysis. For identification of 36 specific organic pigments in tattoo inks, Schreiver et al. (2016) described an analytical method in this journal, which is based on pyrolysis-gas chromatography/mass spectrometry (py-GC/MS). On this basis, there is a perspective to differentiate between more or less harmful pigments.

A pivotal point of the toxicological discussion is the potential carcinogenicity of tattoo inks. At present, skin

Hermann M. Bolt

bolt@ifado.de

1 Leibniz Research Centre for Working Environment and Human Factors at TU Dortmund (IfADo), Adeystr. 67, 44139 Dortmund, Germany cancers on tattoos are considered so far as coincidental, except for keratoacanthomas on red tattoos (Swigost et al. 2019; Kluger 2019b). But irrespective of the lack of epidemiological data, genotoxic and carcinogenic primary aromatic amines or polycyclic aromatic hydrocarbons have been detected as impurities of tattoo inks (Schreiver and Luch 2016).

Another aspect, commented by Schreiver and Luch (2020) in the February issue of this journal, is the introduction of metal debris from tattoo needles containing high amounts of chromium and nickel into the skin. Especially the presence of nickel as a powerful contact allergen is a matter of toxicological concern.

\section{Toxicity of tattoo removal}

Laser irradiation is the most common way to remove unwanted tattoos. Nowadays, primarily organic pigments are used for brilliant colour shades, but such laser irradiation of organic pigments has been shown to produce carcinogenic compounds, e.g. 3,3'-dichlorobenzidine (Hering et al. 2018). Hence, a new avenue of research is the generation of toxic fragments from tattoo inks upon tattoo removal procedures.

This issue of Archives of Toxicology presents two contributions to this topic.

(i) Bauer et al. (2020) report on the products of laser treatment of a specific green tattoo ink. The ink characterisation was carried out by IR, UV-Vis, EDX spectroscopies and SEM imaging. This revealed the presence of pigment PG7, rather than PG36 as reported on the bottle label, along with non-fully halogenated analogues. The ink morphology was an extended sheath with embedded grains. Laser treatments performed on both dried and extracted inks. The products were analysed by gas chromatography-mass spectrometry, UV-Vis spectroscopy, SEM imaging and dynamic light scattering. The outcome was a complex fragmentation pattern that depended 
both on the solvent and on the initial aggregation state. The fragment compounds were toxic at various degrees, according to current classification labelling and packaging (CLP) regulations.

(ii) Hering et al. (2020) establish a reconstructed fullthickness skin model with tattoo pigments, TatS. This new and promising model emulates healed tattooed human skin. It underlines the advantages of 3D over traditional 2D cell culture systems. The methodological approach might be important for further research on the toxicology of tattooing, including used pigments and their destruction for tattoo removal.

\section{Regulatory issues}

In the February issue of this journal Giulbudagian et al. (2020) reviewed current regulatory considerations in the European Union. An exemplary initiative for improving the safety of tattooing is warranted. On the one hand, the compilation of market surveillance data provides knowledge on hazardous substances present in tattoo inks. On the other hand, clinical data from patients now enable the correlation of adverse reactions with certain defined substances.

Nevertheless, the assessment of risks remains a challenge, owing to knowledge gaps on biokinetics of highly complex inks and their degradation products. Giulbudagian et al. (2020) point to strategies for regulating substances in tattoo inks in the light of potential future restrictions in the frame of the European REACH regulation.

Acknowledgements Open Access funding provided by Projekt DEAL.

Open Access This article is licensed under a Creative Commons Attribution 4.0 International License, which permits use, sharing, adaptation, distribution and reproduction in any medium or format, as long as you give appropriate credit to the original author(s) and the source, provide a link to the Creative Commons licence, and indicate if changes were made. The images or other third party material in this article are included in the article's Creative Commons licence, unless indicated otherwise in a credit line to the material. If material is not included in the article's Creative Commons licence and your intended use is not permitted by statutory regulation or exceeds the permitted use, you will need to obtain permission directly from the copyright holder. To view a copy of this licence, visit http://creativecommons.org/licenses/by/4.0/.

\section{References}

Bagot M (2020) Complications des tatouage: classification clinique, histologique, physiopathologique, cinétique des particules. Bull Acad Nat Med. https://doi.org/10.1016/j.banm.2020.04.013

Bauer EM, Scibetta EV, Cecchetti D, Piccirillo S, Antonaroli S, Sennato S, Cerasa M, Tagliatesta P, Carbone M (2020) Treatments of a phthalocyanine-based green ink for tattoo removal purposes: generation of toxic fragments and potentially harmful morphologies. Arch Toxicol. https://doi.org/10.1007/s00204-020-02790-7

Giulbudagian M, Schreiver I, Singh AV, Laux P, Luch A (2020) Safety of tattoos and permanent make-up: a regulatory view. Arch Toxicol 94:357-369. https://doi.org/10.1007/s00204-020-02655s

Hering H, Sung AY, Röder N, Hutzler C, Berlien HP, Laux P, Luch A, Schreiver I (2018) Laser Irradiation of organic tattoo pigments releases carcinogens with 3,3'-dichlorobenzidine inducing DNA strand breaks in human skin cells. J Invest Dermatol 138:26872690. https://doi.org/10.1016/j.jid.2018.05.031

Hering H, Zoschke C, Kühn M, Gadicherla AK, Weindl G, Luch A, Schreiver I (2020) TatS-a novel in vitro tattooed human skin model for improved pigment toxicology research. Arch Toxicol. https://doi.org/10.1007/s00204-020-02825-z

Kluger N (2019a) Tattoo side effects worldwide: a Goggle Trendsbased time series analysis. Acta Dermatovenerologica Alpina, Pannonica et Adriatica 28:125-127. https://doi.org/10.15570/ actaapa.2019.30

Kluger N (2019b) An update on cutaneous complications of permanent tattooing. Expert Rev Clin Immunol. https://doi. org/10.1080/1744666X.2020.1676732

Schreiver I, Luch A (2016) At the dark end of the rainbow: data gaps in tattoo toxicology. Arch Toxicol 90:1763-1765. https://doi. org/10.1007/s00204-016-1740-9

Schreiver I, Luch A (2020) Tattooing: overriding the skin barrier and the journey into the unknown. Arch Toxicol 94:647-648. https:// doi.org/10.1007/s00204-019-02646-9

Schreiver I, Hutzler C, Andree S, Laux P, Luch A (2016) Identification and hazard prediction of tattoo pigments by means of pyrolysisgas chromatography/mass spectrometry. Arch Toxicol 90:16391650. https://doi.org/10.1007/s00204-016-1739-2

Swigost A, Farah RS, Canova E, Goldfarb N (2019) Multiple squameous neoplasms arising in a red tattoo after laser tattoo removal. Dermatol Surg. https://doi.org/10.1097/DSS.0000000000002031

Publisher's Note Springer Nature remains neutral with regard to jurisdictional claims in published maps and institutional affiliations. 